\title{
ФУНКЦИОНАЛЬНЫЕ МАТЕРИАЛЫ, ПОЛУЧЕННЫЕ ИЗ МАКУЛАТУРЫ. II. ЦЕЛЛЮЛОЗНЫЕ ГИДРОГЕЛИ С ВЫСОКОЙ ВОДОУДЕРЖИВАЮЩЕЙ СПОСОБНОСТЬЮ, ПОЛУЧЕННЫЕ ИЗ РАСТВОРОВ БУМАЖНОЙ МАКУЛАТУРЫ В ДМАA/LiCl*
}

\author{
(C) А.М. Михаилиди ${ }^{1 * *}$, Н.Е. Котельникова ${ }^{2}$ \\ ${ }^{1}$ Санкт-Петербургский государственный университет промышленных \\ технологий и дизайна, ул. Б. Морская, 18, Санкт-Петербург, 191186 (Россия), \\ e-mail: amikhailidi@yahoo.com \\ ${ }^{2}$ Институт высокомолекулярных соединений РАН, Большой пр., 31, Санкт- \\ Петербург, 199004 (Россия)
}

\footnotetext{
* Полный текст статьи опубликован: Михаилиди А.М., Котельникова Н.Е. Функциональные материалы, полученные из макулатуры. II. Целлюлозные гидрогели с высокой водоудерживающей способностью, полученные из растворов бумажной макулатуры в ДМАA/LiCl // Химия растительного сырья. 2021. №3. С. 83-98. DOI: 10.14258/jcprm.2021039269.

** Автор, с которым следует вести переписку.
} 


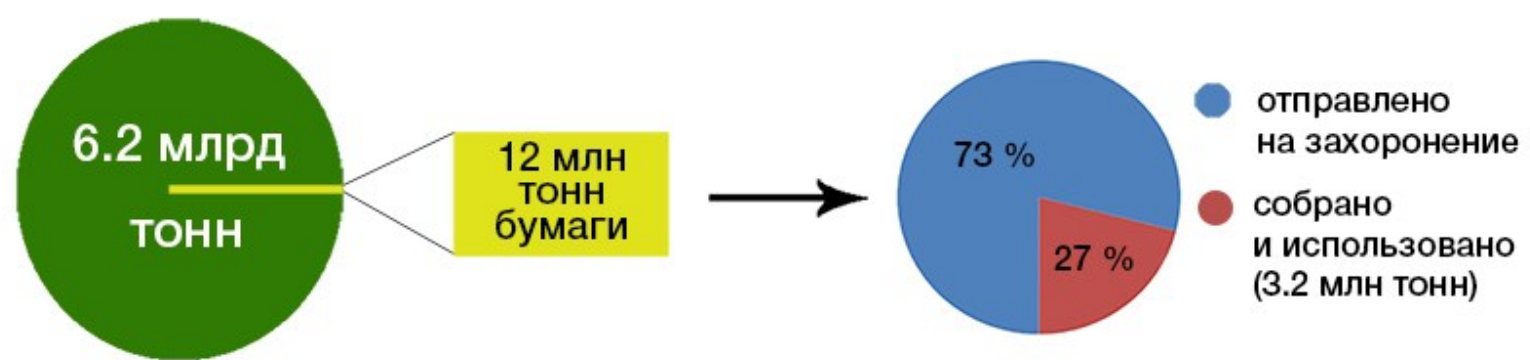

Рис. 1. Обращение с бумажными отходами в России в 2017 г.
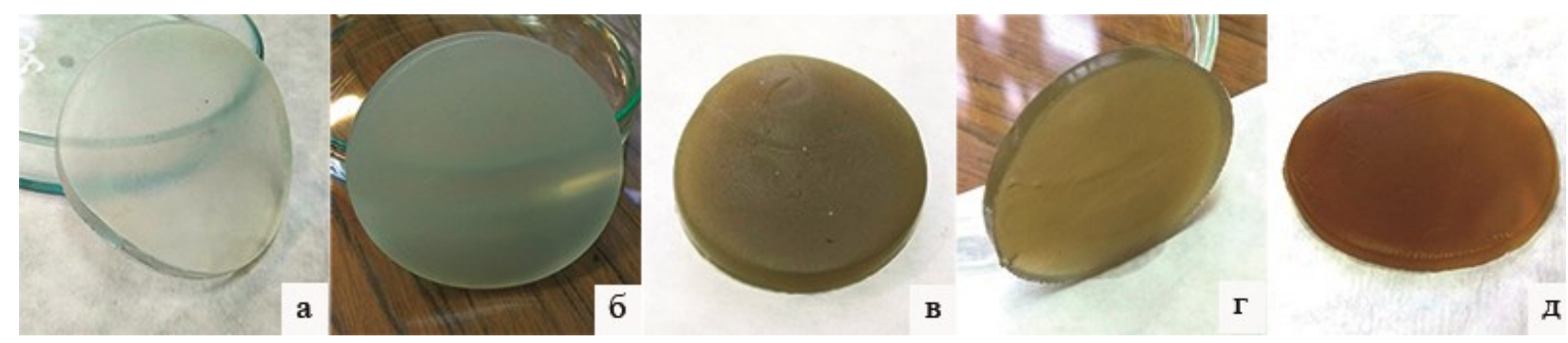

Рис. 2. Гидрогели, полученные из растворов макулатуры в ДМАA/LiCl: $a$ - фильтровального картона К-5, 6 - из картона К-2, в - из газетной бумаги с печатью Г-3, г - из газетной бумаги без печати Г-4, $e-$ из упаковочной бумаги Г-6

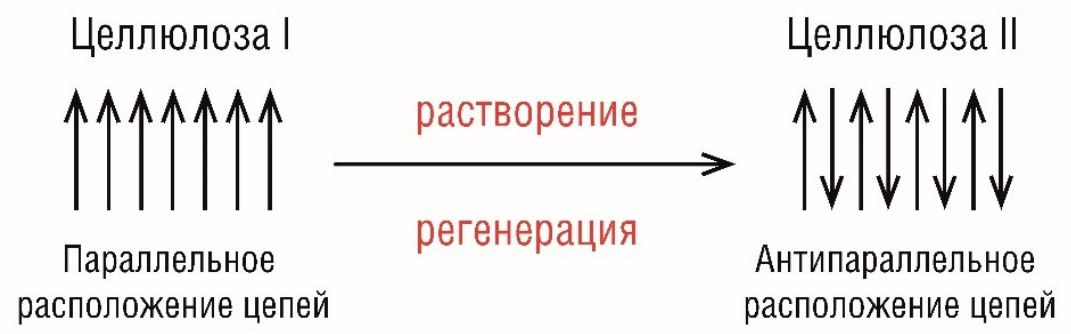

Рис. 3. Перегруппировка целлюлозных цепей при трансформации структуры целлюлозы І в структуру целлюлозы II

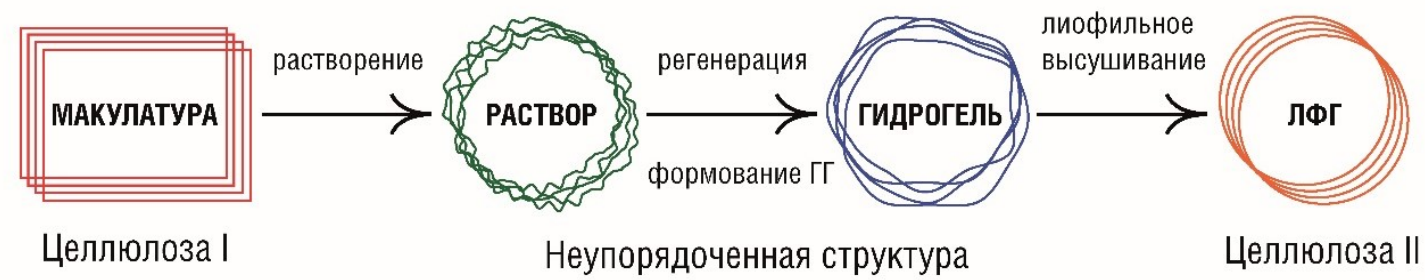

Рис. 4. Структурные изменения целлюлозы при растворении, последующей регенерации, формовании супернабухших гидрогелей и лиофильного высушивания 